\title{
AKIBAT HUKUM PENCAIRAN KREDIT YANG DIDASARKAN PADA COVERNOTE NOTARIS
}

\author{
Silvia Anggraini Yusmi \\ Magang Di Kantor Notaris/PPAT ZUL FADLI, S.H., M.Kn \\ Email: anggrainiyusmis@gmail.com
}

\begin{abstract}
ABSTRAK
Tujuan penelitian ini ialah untuk mengkaji dan menganalisis akibat hukum pencairan kredit yang didasarkan pada covernote notaris. Tipe penelitian yang digunakan dalam penelitian ini ialah penelitian yuridis normatif dengan menggunakan pendekatan undang-undang, pendekatan konseptual, dan pendekatan kasus. Hasil dari penelitian Covernote yang dibuat atas dasar kesepakatan Notaris dan Bank dalam pencairan kredit adalah sah, namun hanya berkedudukan sebagai surat keterangan dari notaris dan tidak memiliki kekuatan hukum karena tidak ada kewenangan Notaris dalam pembuatan suatu Covernote. Akibat hukum pencairan kredit yang didasarkan pada covernote Notaris adalah apabila tidak dapat diselesaikan pengurusan hak tanggungan sesuai dengan covernote yang dibuat oleh Notaris, maka berakibat objek jaminan dalam perjanjian hak tanggungan tidak dapat dieksekusi langsung atau perjanjian hak tanggungan batal demi hukum sedangkan perjanjian kreditnya belum berakhir. Covernote Notaris tidak memiliki kekuatan hukum untuk memberikan perlindungan hukum bagi bank selaku kreditur dalam perjanjian kredit apabila terjadi wanprestasi pada saat proses pembebanan hak jaminan. Notaris dapat dimintakan pertanggungjawaban atas kesalahannya jika dalam penerbitan covernote tersebut terdapat unsur yang memuat keterangan yang tidak benar terhadap isi covernote tersebut.
\end{abstract}

Kata Kunci: Covernote, Notaris, Perbankan

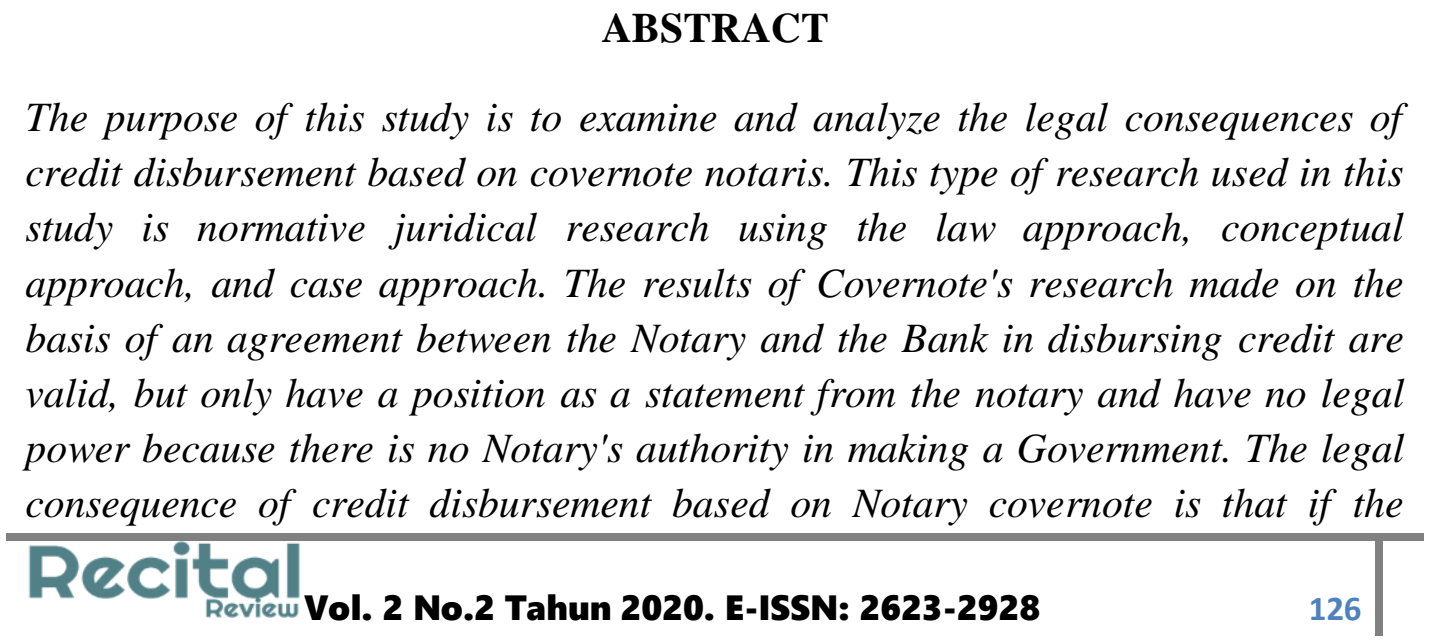


management of mortgage rights cannot be completed in accordance with the covernote made by the Notary Public, the object of collateral in the mortgage agreement cannot be executed immediately or the mortgage agreement is null and void while the credit agreement has not yet ended. Covernote Notary does not have the legal power to provide legal protection for banks as creditors in credit agreements in the event of defaults during the process of assigning collateral rights. The notary can be held liable for his mistakes if in the issuance of the covernote there are elements which contain incorrect information about the contents of the covernote.

Keywords: Covernote, Notary, Banking

\section{LATAR BELAKANG}

Keberhasilan pembangunan nasional dalam bidang ekonomi dapat dilihat dengan cara meningkatkan produksi nasional, menjaga stabilitas ekonomi, membuka kesempatan kerja, mengusahakan kenaikan pendapatan nasional, mampu menjaga neraca pembayaran luar negeri agar tidak defisit dan pemerataan distribusi pendapatan. Bank memiliki peran penting untuk mendukung jalannya pembangunan dan menjaga kestabilan ekonomi bagi negara terkait dengan fungsinya sebagai sebuah lembaga yang bertugas menghimpun dana yang kemudian menyalurkan dana yang berasal dari masyarakat tersebut dengan cara yang efektif serta efisien.

Pasal 1 angka 11 UU Perbankan disebutkan bahwa "Kredit adalah penyediaan uang atau tagihan yang dapat dipersamakan dengan itu, berdasarkan persetujuan atau kesepakatan pinjam-meminjam antara bank dengan pihak lain yang mewajibkan pihak peminjam untuk melunasi utangnya setelah jangka waktu tertentu dengan pemberian bunga." "Untuk menganalisis suatu permohonan kredit pada umumnya digunakan kriteria 5C's Principles, yakni Character (watak), Capacity (kemampuan), Capital (modal), condition of economy (kondisi perekonomian), Collateral (Jaminan atau Agunan)."1 Perjanjian kredit merupakan perjanjian pokok (perjanjian utama) yang harus dilaksanakan ketika kedua belah pihak yaitu debitur dan kreditur telah sepakat untuk memberikan dan menggunakan fasilitas kredit yang disediakan oleh bank. Pada perjanjian kredit biasanya disertakan pula adanya jaminan kebendaan tersebut yang harus dibuatkan dalam suatu perjanjian jaminan yang memiliki hak kebendaan dan bersifat assecoir (tambahan). "Agunan dalam pemberian kredit merupakan

${ }^{1}$ Sentosa Sembiring, 2000, Hukum Perbankan, CV. Mandar Maju, Bandung, hlm. 6869. 
perjanjian tambahan dalam arti, bila debitur tidak mampu melunasi utangnya, maka agunan tersebut akan dilelang untuk melunasi utang-utang tersebut."2

Perjanjian kredit yang dibuat oleh debitur dengan kreditur adalah perjanjian pokok yang menyangkut hutang-piutang, dimana kreditur selaku pihak yang berpiutang sedangkan debitur selaku pihak yang berhutang, dan untuk lebih mengikat perbuatan hukum antara para pihak biasanya dibuatkan perjanjian secara autentik oleh Notaris. $^{3}$

Keberadaan Notaris di Indonesia saat ini semakin dibutuhkan oleh masyarakat, terutama yang berkaitan dengan perbuatan hukum yang bersifat hukum privat(perdata). Pekerjaan Notaris merupakan pekerjaan yang melayani jasa akan kebutuhan masyarakat yang melakukan suatu perbuatan hukum, perjanjian atau suatu penetapan yang diharuskan oleh undang-undang atau yang dikehendaki oleh para pihak yang membuatnya. Selain akta-akta yang dibuat oleh Notaris terdapat surat yang menjadi objek penelitian ini yaitu berupa covernote yang umum diterbitkan oleh Notaris terkait permintaan untuk peminjaman kredit kepada lembaga perbankan.

Covernote adalah sebuah surat yang isinya merupakan keterangan yang dibuat oleh seorang Notaris dimana covernote tersebut dibuat oleh Notaris pada saat telah terjadi perjanjian kredit dengan tujuan untuk menjadikan perjanjian yang mengikat agunan atau jaminan dari sebuah perjanjian kredit yang dikeluarkan bank. Bank dalam hal ini bertindak selaku kreditor atau pemberi kredit. Covernote sangat dibutuhkan oleh kreditur selaku pihak yang pemberi pinjaman (berpiutang), karena memuat kesanggupan dari Notaris dalam menjalankan isi dari covernote tersebut. Tanpa adanya covernote, pihak bank (kreditur) belum bisa untuk mencairkan dana atau fasilitas kredit kepada debitur.

Notaris mengeluarkan covernote karena Notaris belum tuntas menyelesaikan pekerjaannya dalam kaitannya dengan tugas dan kewenangannya untuk menerbitkan akta otentik. "Dalam permohonan perjanjian kredit, apabila persyaratan untuk kelengkapan permohonan pengajuan kredit belum lengkap secara keseluruhan, seperti mengenai dokumen penjaminan." ${ }^{4}$ isi covernote tersebut memuat mengenai telah ditandatanganinya perjanjian kredit, antara pihak debitur dengan kreditur, telah diserahkannya jaminan sebagai agunan oleh debitur kepada kreditur, telah ditandatanganinya akta pemberian hak tanggungan, namun semuanya itu masih dalam proses oleh Notaris. "Kondisi ini disebabkan tanah

${ }^{2}$ Ibid, hlm 69.

3 I Dewa Made Dwi Sanjaya, 2017, 'Tanggung Jawab Hukum Notaris Terhadap Penerbitan Covernote Dalam Pemberian Kredit', Riau Law Jurnal, Vol 1, hlm. 182.

${ }^{4}$ Bonny Oktafian, Ridwan, and Achmad Syarifuddin, 2019, 'Legalisasi Perjanjian Kredit Oleh Notaris Yang Berbeda Dengan Notaris Pembuat Covernote, Repertorium Jurnal Ilmiah Hukum Kenotariatan, Vol 8, hlm 84. 
sebagai objek jaminan belum mempunyai bukti kepemilikan yang sah, belum didaftarkan sehingga belum bisa dijadikan sebagai objek jaminan dalam bentuk hak tanggungan." 5

Kondisi kekosongan norma (vacum of norm) ini menyebabkan ketiga unsur tersebut tidak mendapat kepastian hukum dari pada kekuatan hukum Covernote tersebut dan begitu vitalnya peran covernote dalam dunia perbankan sehingga perlu atas suatu kepastian hukum mengenai kekuatan hukum covernote karena pengaturan covernote tidak ada didalam UU Jabatan Notaris maupun Peraturan Pemerintah Nomor 24 Tahun 2016 Tentang Perubahan Atas Peraturan Pemerintah Nomor 37 Tahun 1998 tentang Peraturan Jabatan Pembuatan Akta Tanah.

\section{PERMASALAHAN}

Berdasarkan latar belakang masalah di atas, dapat dirumuskan masalah sebagai berikut:

1. Bagaimana keabsahan covernote yang dibuat berdasarkan kesepakatan para pihak dalam pencairan kredit perbankan ?

2. Bagaimana akibat hukum pencairan kredit yang didasarkan pada covernote Notaris?

\section{METODE PENELITIAN}

Penelitian yang digunakan ialah jenis peneliitian yuridis normatif dengan menggunakan pendekatan penelitian pendekatan undang-undang, pendekatan konseptual, dan pendekatan kasus. Bahan hukum yang digunakan ialah bahan hukum primer, bahan hukum sekunder, dan bahan hukum tersier.

\section{PEMBAHASAN}

\section{Keabsahan Covernote Yang Dibuat Berdasarkan Kesepakatan Para Pihak Dalam Pencairan Kredit Perbankan}

Salah satu bisnis utama perbankan yaitu kredit, karena dari kredit bank mendapatkan keuntungan yang besar baik keuntungan dari kegiatan menghimpun dana masyarakat lalu menyalurkan kepada masyarakat yamg memerlukannya untuk modal usaha dan bisnis dari berbagai biaya yang menyertai pemberian kredit. Cakupan dari kredit yang merupakan suatu bidang usaha dari perbankan sangat luas serta membutuhkan profesionalisme serta integritas moral yang tinggi. Arti utama dari pengertian kredit itu sendiri adalah kepercayaan.

Bank selaku kreditur mencairkan fasilitas kredit setelah nasabah selaku debitur telah melengkapi semua persyaratan pengajuan permohonan kredit,

${ }^{5}$ Ibid, hal 85. 
sehingga bank memiliki rasa kepercayaan terhadap debitur, bahwa debitur mampu membayar kembali pinjamannya. Untuk nilai jaminan yang dijadikan agunan oleh debitur, bank juga membutuhkan bahwa nilai jaminan dan objek yang dijadikan jaminan harus mempunyai nilai yang lebih tinggi dibandingkan dengan jumlah pinjaman. Hal tersebut dilakukan karena untuk menjamin jika debitur tidak mampu untuk melunasi hutangnya, maka bank dalam pencairan objek jaminan tetap dapat mengambil jumlah piutangnya dari jaminan tersebut.

Calon nasabah yang menginginkan dana atau uang dari Bank oleh karena persyaratan Bank akan mencairkan kredit ketika ada hak agunan yang dijaminkan (Pasal 8 Undang-Undang Hak Tanggungan), calon debitur bersama-sama ke Notaris untuk dibuatkan SKMHT, dengan pihak Bank kemudian calon debitur memberikan kuasa kepada Bank melalui SKMHT melalui surat yang dibuat Notaris. Dalam praktik lapangan biasanya Bank kreditur yang melakukan pendaftaran APHT ke Badan Pertanahan untuk kemudian dikeluarkan sertifikat hak tanggungan yang dapat dijadikan jaminan dan Bank memiliki kekuatan untuk mengakui objek jaminan jika debitur pemberi hak tanggungan tidak memenuhi kewajiban pembayaran utamanya. ${ }^{6}$

Munculnya covernote ini pada saat proses sertifikat hak tanggungan dan Notaris membuatkan covernote agar bank percaya bahwa proses penerbitan hak tanggungan pasti akan diselesaikan oleh Notaris. Dengan adanya covernote yang dibuat oleh Notaris sebagai surat keterangan bahwa sertifikat hak tanggungan sedang dalam proses dan dengan covernote, bank selaku kreditur dapat mencairkan fasilitas kredit yang diberikan kepada debitur.

Notaris sebagai rekanan pihak bank akan diminta oleh bank untuk membuatkan perjanjian kredit dalam bentuk akta otentik yang kemudian diikuti dengan dibuatnya akta pengikatan jaminan sertifikat hak milik dari debitur, karena debitur meminjam uang kepada kreditur sebagaimana yang telah disepakati oleh bank selaku kreditur dan debitur. Pihak perbankan yang akan mencairkan fasilitas kredit kepada debitur sepenuhnya mempercayakan proses pengikatan jaminan sertifikat hak milik debitur dari awal sampai dengan selesai dan telah ada bukti pengikatan pengikatan hak tanggungan yang telah didaftarkan ke Badan Pertanahan Nasional dan sertifikat tersebut sampai ke tangan pihak bank.

Pengikatan jaminan sertifikat hak milik membutuhkan proses yang cukup lama dan tadi tidak dapat langsung selesai bersamaan dengan selesainya dan ditandatanganinya perjanjian kredit. Untuk keperluan pihak perbankan dalam memberikan dan mencairkan fasilitas kredit kepada debitur, maka dari itu pihak bank meminta kepada Notaris untuk dibuatkan surat keterangan atau yang biasa

${ }^{6}$ Andri Firdaus, Wawancara Staff Bagian Kredit Bank Jambi. 
disebut covernote yang isi dari surat tersebut adalah menerangkan bahwa proses pemasangan hak tanggungan sedang berjalan dan surat ketarangan dibuat Notaris tersebut dapat dipergunakan sebagaimana mestinya. Dengan adanya covernote yang dikeluarkan oleh Notaris tersebut, maka pihak perbankan dapat mempercayakan kepada Notaris dan pihak bank dapat menyalurkan fasilitas kredit kepada debitur sesegera mungkin.

Fungsi yang diperlukan dari covernote merupakan hal yang harus digaris bawahi dalam praktik Notaris membuat covernote dalam dalam dunia perbankan. Dalam pencairan fasilitas kredit perbankan kepada nasabah, covernote memiliki nilai ekonomis. Covernote digolongkan dalam sumber hukum formil yaitu sumber hukum yang berdasarkan kebiasaan. Kebiasaan merupakan apa yang dilakukan oleh manusia secara berulang-ulang dan terus menerus. Penggunaan covernote itu dilakukan secara berulang-ulang dan terus menerus dilakukan yang kemudian diterima oleh masyarakat, maka covernote telah menjadi kebiasaan dalam masyarakat. Mohammad Sigit Gunawan menyebutkan pula bahwa:

Surat keterangan Notaris sendiri tidak memiliki landasan hukum normative, melainkan hanya berlandaskan pada hukum kebiasaan. Peran covernote adalah untuk meyakinkan pihak bank bahwa calon debitor akan segera menyelesaikan persyaratan, melunasi dokumen syarat, serta menyelesaikan segala hal yang terkait dengan benda yang menjadi objek agunan. Pihak bank percaya bahwa dengan keluarnya surat ini pihak debitor akan menyelesaikan kewajibannya segera. Namun di luar daripada itu, bagi debitor, surat ini bertindak sebagai surat yang mempermudah proses pencairan dana pinjaman. Melalui surat ini keduanya tidak mendapat kerugian satu dengan yang lain dengan catatan, keduanya tidak mencederai isi surat keterangan tersebut. ${ }^{7}$

Menurut Teori kepastian hukum yang dikemukakan oleh Utrecht, bahwa adanya aturan yang bersifat umum membuat individu mengetahui perbuatan apa yang boleh atau tidak boleh dilakukan. ${ }^{8}$ Berdasarkan teori tersebut, Notaris dalam mengeluarkan covernote sebagai dasar dari pencairan fasilitas kredit perbankan harus berhati-hati karena tidak adanya aturan mengenai covernote. Hasil penelitian yang dilakukan oleh Dwi Wahyu Juliyanto menunjukan bahwa problematika dari covernote tersebut yaitu "tidak ada satu pasalpun dalam Undang-Undang Jabatan Notaris yang dapat ditafsirkan sebagai kewenangan Notaris untuk mengeluarkan surat keterangan yang disebut sebagai covernote

7 Mohammad Sigit Gunawan, 2018, 'Peran Dan Fungsi Covernote Notaris Pada Peralihan Kredit (Take Over) Pada Bank', Jurnal Ilmiah Indonesia, hlm, 84-85.

${ }^{8}$ Riduan Syahrani, 1999, Rangkuman Intisari Ilmu Hukum, Citra Aditya Bakti, Bandung, hlm 23 
menjadi problematika tersendiri." 9

Covernote bukan akta otentik walaupun covernote dibuat oleh Notaris sebagai pejabat umum, tapi covernote hanya merupakan surat keterangan biasa yang isinya menyatakan mengenai kesanggupan Notaris dalam menyelesaikan pekerjaannyaterkait dengan proses penyelesaian sertifikat hak tanggungan. Dalam proses pembuatan penggunaan covernote melibatkan Notaris dan Kreditur. Bank dalam hal ini sebagai kreditur yang bergerak dalam bidang jasa keuangan yang mempunyai peran menghimpun dan dari masyarakat kemudian menyalurkannya kembali kepada masyarakat dalam bentuk jasa fasilitas kredit. Artinya dalam hal ini Notaris dan Bank sepakat mengenai penerbitan covernote oleh Notaris dalam pencairan kredit.

Covernote muncul karena pada prakteknya sangat dibutuhkan oleh pihak perbankan dan covernote hanya mengikat Notaris apabila Notaris mengakui tanda tangan yang ada pada covernote tersebut. Covernote bukan bukti jaminan. Covernote Notaris hanya berlaku sebagai keterangan bahwa telah terjadi perjanjian kredit dan pengikatan jaminan. Covernote dalam dunia perbankan hanyalah surat keterangan biasa yang dibuat oleh Notaris yang isinya menerangkan bahwa masih terjadi proses yang masih harus diselesaikan oleh Notaris sampai dengan pengikatan hak tanggungan selesai. Covernote bukanlah kelengkapan berkas, hanya sebagai pegangan bank bahwa ternyata benar berkas tersebut masih dalam proses, asas kepercayaan sangat penting bagi bank dan Notaris yang mengeluarkan covernote.

Fungsi covernote yang dikeluarkan oleh Notaris dalam hal pencairan kredit oleh bank sebagai kreditur kepada debitur yaitu hanya sebagai pegangan bank. Sebagai produk hukum Notaris, covernote tidak memiliki kekuatan hukum apapun, karena covernote hanyalah surat biasa yang isinya menerangkan bahwa Notaris belum menyelessaikan pekerjaannya atau pekerjaannya terkait dengan pross pengikatan jaminan masih dalam prooses. Covernote bukan akta otentik dan juga bukan akta di bawah tangan. Tidak ada yang mengatur kewenangan Notaris dalam pembuatan covernote, walaupun Covernote dibuat oleh yaitu Notaris. Covernote hanyalah suatu kebiasaan yang terjadi dalam praktek Notaris terutama dalam kaitannya dengan dunia perbankan.

\section{Akibat Hukum Pencairan Kredit Yang Didasarkan Pada Covernote Notaris}

Bank dan debitur yang membuat perjanjian kredit dengan mempergunakan jaminan pada umumnya akan diikat dengan akta Notaris yang kemudian akan diproses pembebanan jaminan. Notaris akan mengeluarkan covernote kapada bank

9 Dwi Wahyu Juliyanto dan Moch Najib Imanullah, 2018, 'Problematika Covernote Notaris Sebagai Pegangan Bank Untuk Media Realisasi Pembiayaan / Kredit Dalam Dunia Perbankan', Repertorium Jurnal Pemikiran Dan Penelitian Bidang Keprdataan Dan Kenotariatan, hlm, 61 . 
selaku pihak yang berpiutang, karena proses pembebanan jaminan yang belum selesai dilakukan. Notaris menyatakan dalam covernote tersebut bahwa sanggup membantu bank dan calon debitur yang akan mengajukan permohonan kredit untuk melengkapi syarat dari pencairan kredit dalam proses perjanjian kredit, pendafataran hak atas tanah sampai dengan selesainya pembuatan sertifikat hak tanggungan.

Selama prestasi dalam perjanjian kredit yang dijaminkan dengan Hak Tanggungan dipenuhi dengan baik oleh debitor, maka Hak Tanggungan sebagai hak jaminan tidak kelihatan fungsinya. Hak Tanggungan baru berfungsi apabila debitur cedera janji (wanprestasi). ${ }^{10}$ Akibat hukum tidak selesainya pengurusan pendaftaran hak tanggungan memiliki beberapa akibat hukum karena dapat diketahui bahwa tidak selesainya pendaftaran hak tanggungan terdapat beberapa masalah hukum yang dapat terjadi. Akibat hukum terhadap para pihak yang tidak menyelesaikan pengurusan hak tanggungan sesuai dengan keterangan yang dituangkan dalam covernote yang dibuat oleh Notaris masih berlanjut. Dapat diketahui bahwa perjanjian hak tanggungan merupakan perjanjian tambahan, jika perjanjian tambahan batal, tidak mengakibatkan perjanjian utamnya yaitu perjanjian kredit batal. Jika para pihak tidak dalam perjanjian kredit tidak menyelesaikan proses pendaftaran hak tanggungan sebagaimana yang disebutkan dalam covernote, maka akan menimbulkan akibat hukum.

Berdasarkan Pasal 1381 KUHPerdata dapat dipahami bahwa perjanjian kredit tidak akan berakhir apabila serjanjian tambahannya berakhir. Proses penyelesaian pendaftaraan hak tanggungan yang tidak dapat diselesaikan sesuai keterangan covernote yang dibuat oleh Notaris bukan merupakan suatu syarat berakhirnya perjanjian yang diatur berdasarkan Pasal 1381 KUHPerdata. Berdasarkan Pasal 1381 KUHPerdata bahwa proses penyelesaian pendaftaraan hak tanggungan yang tidak dapat diselesaikan sesuai keterangan covernote yang dibuat oleh Notaris yang dapat dijadikan sebagai sebab batalnya perjanjian kredit, apabila penyelesaian pendaftaran hak tanggungan tidak dapat diselesaikan dijadikan sebagai suatu syarat batalnya perjanjian yang diatur dalam perjanjian kredit antara debitur dan kreditur maka berdasarkan hal tersebut dapat saja kreditur untuk membatalkan suatu perjanjian.

Berdasarkan Pasal 1266 KUHPerdata, berlakunya syarat batal dalam suatu peristiwa hukum bahwa tidak mengakibatkan secara langsung perjanjian tersebut berakhir, akan tetapi dalam pembatalannya harus dimintakan kepada pengadilan. Berdasarkan hal tersebut dapat dipahami bahwa tidak dapat diselesaikannya pengurusan hak tanggungan dimana tidak sesuai dengan covernote yang dibuat

${ }^{10}$ Novy Dyah Rahmanti, 2020, ‘Ada Apa Dengan SKMHT?', Recital Review, Vol 2.1, hlm. 59. 
oleh Notaris, jika bank selaku kreditur ingin membatalkan suatu perjanjian kredit tersebut sehingga berlakunya suatu syarat batal dalam perjanjian tetap harus dimintakan pembatalannya melalui penetapan pengadilan. Pasal 1265 KUHPerdata, akibat hukum berlakunya suatu syarat batal akan menghapuskan perikatan dan seolah-olah dari awal tidak ada perikatan. Dengan berlakunya syarat batal maka kreditur wajib mengembalikan apa yang telah diterimanya. Berdasarkan hal tersebut dapat diketahui bahwa akibat hukum terhadap para pihak debitur apabila tidak dapat diselesaikan pengurusan hak tanggungan sesuai dengan covernote yang dibuat oleh Notaris sehingga menyebabkanya terpenuhinya syarat batalnya suatu perjanjian, maka berakibat pihak debitur mengembalikan uang hasil pencairan fasilitas kredit yang diberikan oleh bank sebagai kreditur.

Akibat hukum apabila tidak dapat diselesaikan pengurusan hak tanggungan sesuai dengan covernote yang dibuat oleh Notaris jika perjanjian kredit tersebut dapat dibatalkan oleh Bank selaku kreditur maka debitur wajib mengembalikan uang hasil pencairan fasilitas kredit yang diberikan kepada debitur. Kemudian jika perjanjian kredit tidak dibatalkan oleh bank maka perjanjian kredit tetap sah sehingga debitur tetap wajib memenuhi prestasi yang diperjanjikan dalam suatu perjanjian kredit sepertinya halnya hutang pokok, bunga dan lain-lain. Tidak selesainya pengurusan hak tanggungan hanya berakibat objek jaminan dalam perjanjian hak tanggungan tidak dapat dieksekusi langsung atau perjanjian hak tanggungan batal demi hukum sedangkan perjanjian kreditnya belum berakhir.

Hasil penelitian yang dilakukan oleh Dewi Rachmayani dan Agus Suwandono menunjukan bahwa "penggunaan covernote notaris dalam perjanjian kredit dapat menyebabkan kerugian bank manakala terjadi wanprestasi sedangkan proses pengikatan hak tanggungan belum selesai." 11 Penggunaan Covernote juga tidak dapat menjamin bahwa tidak akan terjadi permasalahan apabila Notaris/PPAT belum bisa menyelesaikan proses pensertifikatan dan terjadi kredit macet, pihak perbankan tidak dapat mengeksekusi jaminan, karena proses pendaftaran hak tanggungan belum selesai sehingga berakibat hukum pihak bank selaku kreditur yang akan dirugikan. Maka dari hal itu, jika suatu saat nanti covernote dijadikan alat bukti di pengadilan, covernote hanya memiliki kekuatan sebagai surat biasa, bukti permulaan atau alat bukti tambahan yang penilaiannya diserahkan kepadda hakim.

Covernote Notaris/PPAT tidak memiliki kekuatan hukum untuk memberikan perlindungan hukum bagi bank selaku kreditur dalam perjanjian kredit apabila terjadi wanprestasi oelh debitur pada saat proses pembebanan

11 Dewi Rachmayani dan Agus Suwandono, 2017, 'Notaris Dalam Perjanjian Kredit Dalam Perspektif Hukum Jaminan', Acta Diurnal Jurnal Hukum Kenotariatan Dan Ke-PPAT-An, Vol 1, hlm 73 
jaminan. Akibat hukum dari penggunaan covernote yang dijadikan dasar pencairan kredit oleh bank yaitu tidak adanya perlindungan hukum bagi bank dalam perjanjian kredit dalam hal terjadinya wanprestasi sebelum terbitnya hak tanggungan. Bank hanya berkedudukan hanya sebagai kreditur konkuren bukan kreditur preferen. Perlindungan hukum bagi bank didasarkan Pasal 1131 dan 1132 KUHPerdata. Penyelesaian kredit dapat diselesaikan melalui litigasi melalui gugatan wanprestasi maupun gugatan kepailitan, atau melalui non litigasi.

Pelayanan hukum yang diberikan Notaris kepada masyarakat adalah tugas dari jabatan Notaris yang merupakan jabatan yang dipercaya dalam hal melaksanakan profesinya sebagai Notaris. Alat bukti otentik sangat diperlukan untuk memberikan jaminan kepastian hukum, ketertiban hukum, serta perlindungan hukum, maka dari itu di perlukan adanya alat bukti otentik. Notaris merupakan pejabat yang menjalankan profesinya dan diberi kewenangan membuat akta otentik yang menyangkut tentang suatu keadaan, suatu peristiwa, atau penyelenggaraan perbuatan hukum melalui jabatan tertentu yang bertujuan untuk memberikan pelayanan hukum bagi masyarakat. Tidak ada yang melarang penggunaan covernote notaris dalam perjanjian kredit. Namun dalam hal penerbitan covernote, Notaris harus berhati-hati dalam memeriksa kebenaran dokumen yang menjadi syarat dalam perjanjian kredit. Notaris dapat dimintakan pertanggungjawaban atas kesalahannya jika dalam penerbitan covernote tersebut terdapat unsur yang memuat keterangan yang tidak benar atau pemalsuan keterangan terhadap isi covernote tersebut. Tanggung jawab Notaris dalam menerbitkan covernote yang menjadi dasar pencairan kredit perbankan adalah Notaris bertanggung jawab penuh atas isi dari covernote yang diterbitkannya. Bank selaku kreditur memgang covernote sebagai bukti bahwa dokumendokumen yang terkait dengan pencairan fasilitas kredit perbankan sedang dalam pengurusan oleh Notaris sehingga bank atas dasar covernote tersebut dapat segera mencairkan dana dari fasiltas kredit yang dimohonkan oleh debitur.

Notaris dituntut untuk dapat bertanggung jawab jika ternyata gagal dalam menjalankan isi covernote tersebut. Pada dasarnya lahirnya covernote tersebut adalah hasil dari kesepakatan antara bank dengan Notaris, di mana Notaris bersedia untuk menjalankan apa yang diminta oleh bank terkait perjanjian kredit, pembuatan akta pemberian hak tanggungan atau pengikatan jaminan sertifikat hak milik.

Kemudian teori pertanggungjawaban digunakan penulis untuk menjawab permasalahan terkait dengan tanggungjawab Notaris dalam kaitannya dengan akibat hukum Notaris yang menerbitkan covernote, namun ternyata gagal dalam menjalankan isi dari covernote itu sendiri. Teori ini sangat erat hubungannya dengan tangungjawab Notaris dalam menerbitkan covernote untuk kepentingan pihak perbankan. Berdasarkan teori dari Hans Kelsen mengenai tanggung jawab 
hukum, yaitu "Satu konsep yang berhubungan dengan konsep kewajiban hukum adalah tanggung jawab hukum." 12 Dalam teori tersebut menjelaskan bahwa seseorang bertanggungjawab secara hukum atas perbuatan tertentu atau bahwa dia memikul tanggung jawab hukum, berarti bahwa dia bertangpungjawab atas suatu sanksi dalam hal perbuatan yang bertentangan. Notaris dapat dimintakan pertanggungjawaban atas kesalahannya jika dalam penerbitan covernote tersebut terdapat unsur yang memuat keterangan yang tidak benar terhadap isi covernote tersebut. Teori tanggungjawab hukum sangat erat kaitannya dengan tanggung jawab hukum Notaris di dalam menerbitkan covernote untuk kepentingan para pihak yang bersangkutan. Walaupun di dalam Undang-Undang Jabatan Notaris tidak mengatur covernote ini, tetapi demi kepentingan pihak yang membutuhkannya Notaris wajib menerbitkannya, sesuai dengan tugas dan tanggung jawabnya sebagai pejabat umum yang melayani kepentingan publik.

Notaris dapat dimintakan pertanggungjawaban atas kesalahannya jika dalam penerbitan covernote tersebut terdapat unsur yang memuat keterangan palsu terhadap isi covernote tersebut. "Ketidaksesuaian yang terjadi antara pernyataan dalam covernote dengan realitasnya di lapangan, Notaris harus bertanggung jawab, baik secara pidana ataupun perdata dan bahkan bertanggung jawab secara moral." $" 13$

Kasus dalam Putusan Pengadilan Negeri Malang Nomor 217/Pdt.G/2017/PN.Mlg adalah salah satu contoh kasus Covernote Notaris. Bahwa pembuatan Akta Jual Beli Bangunan dan Pelepasan Hak Atas Tanah Nomor 99 tanggal 25 Agustus 2011 beserta Cover Note yang dibuat oleh Tergugat II yang selanjutnya dipergunakan oleh Tergugat I untuk membuat perjanjian kredit dengan Turut Tergugat yang mengakibatkan timbulnya kerugian bagi Para Penggugat menurut Majelis Hakim merupakan perbuatan melawan hukum, oleh karena pembuatan Perjanjian Kredit antara Tergugat I dengan Turut Tergugat yang dicatatkan melalui Tergugat II yang tidak memenuhi syarat materiil yang dibuat tanpa sepengetahuan dari Para Penggugat selaku pemilik obyek sengketa yang sah. Akibat hukum dari covernote Notaris yang dijadikan dasar dalam pencairan fasilitas kredit pada putusan pengadilan tersebut, pemberian jaminan merupakan perbuatan melawan hukum karena pemberi jaminan bukan yang berhak dalam memberikan jaminan kebendaan tersebut. Apabila terjadi hal tersebut maka akibat hukumnya batalnya demi hukum perjanjian pemberian jaminan hak tanggungan akan tetapi perjanjian kredit masih dapat tetap berlanjut karena perjanjian jaminan hanya sebuah perjanjian tambahan.

12 Hans kelsen, 2014, Teori Umum Tentang Hukum Dan Negara, General Theory Of Law and State, Terjemahan Raisul Muttaqien, Nusa Media, Bandung, hlm 95.

13 Rahmiah Kadir 2018, 'Pertanggungjawaban Notaris Pada Penerbitan Covernote', Repertorium Jurnal Ilmiah Hukum Kenotariatan, hlm, 203. 
Covernote dapat termasuk dalam perbuatan melawan hukum menurut Pasal 263 KUH Pidana, apabila covernote yang dibuat oleh Notaris tersebut telah sengaja memberi keterangan palsu. Pasal tersebut menyebutkan bahwa, barang siapa membuat surat palsu atau memalsukan surat yang dapat menimbulkan sesuatu hak, perikatan atau pembebasan hutang, atau yang diperuntukkan sebagai bukti daripada sesuatu hal dengan maksud untuk memakai atau menyuruh orang lain memakai surat tersebut seolah-olah isinyabenar dan tidak dipalsu, diancam jika pemakaian tersebut dapat menimbulkan kerugian, karena pemalsuan surat, dengan pidana penjara paling lama enam tahun.

Berdasarkan UUJN dan Peraturan Kepala BPN Nomor 1 Tahun 2006 tentang Ketentuan Pelaksanaan Peraturan Pemerintah Nomor 37 Tahun 1998 tentang Peraturan Jabatan PPAT diketahui bahwa ancaman hukuman penjara diatas 5 tahun dapat diberhentinkan dari jabatan Notaris sehingga dapat diketahui bahwa keterangan palsu dengan sengaja akan memberikan akibat hukum terhadap Notaris diberhentikan dengan tidak hormat teramasuk keterangan palsu atas covernote yang dibuat oleh Notaris berkaitan dengan penyelesaian proses hak tanggungan dalam suatu perjanjian kredit.

\section{KESIMPULAN}

Covernote yang dibuat atas dasar kesepakatan Notaris dan Bank dalam pencairan kredit adalah sah, namun hanya berkedudukan sebagai Surat Keterangan dari Notaris untuk Bank yang akan mengeluarkan kredit yang berisikan tentang masih terjadinya proses yang masih harus dilakukan untuk pengikatan suatu jaminan sehingga menjadi Hak Tanggungan. Kekuatan hukum Covernote sebagai produk hukum Notaris tidaklah memiliki kekuatan hukum apapun. Akibat hukum pencairan kredit yang didasarkan pada covernote Notaris adalah apabila tidak dapat diselesaikan pengurusan hak tanggungan sesuai dengan covernote yang dibuat oleh Notaris hanya berakibat objek jaminan dalam perjanjian hak tanggungan tidak dapat dieksekusi langsung atau perjanjian hak tanggungan batal demi hukum sedangkan perjanjian kreditnya belum berakhir. Covernote Notaris tidak memiliki kekuatan hukum untuk memberikan perlindungan hukum bagi bank selaku kreditor dalam perjanjian kredit apabila terjadi wanprestasi pada saat proses pembebanan jaminan masih dilakukan oleh Notaris/PPAT. Notaris dapat dimintakan pertanggungjawaban atas kesalahannya jika dalam penerbitan covernote tersebut terdapat unsur yang memuat keterangan yang tidak benar terhadap isi covernote tersebut.

\section{SARAN}

Untuk pengaturan covernote kedepannya agar diatur dalam peraturan perundang-undangan karena dapat diketahui bahwa pentingnya keberadaan 
covernote sebagai keterangan yang memberikan informasi atas suatu proses hukum yang berkaitan dengan tugas jabatan Notaris /PPAT. Bagi pihak Bank dan Notaris agar covernote tidak dijadikan sebagai dasar pencairan kredit dalam perjanjian kredit dalam perbankan kedepannya karena covernote bukan suatu jaminan dan juga tidak ada aturan dalam peraturan perundan-undangan yang mengatur mengenai covernote sehingga berdasarkan hal tersebut sangat berisiko bagi perbankan untuk menerapkannya sebagai dasar pencairan kredit dalam perbankan.

\section{DAFTAR PUSTAKA}

Andri Firdaus, 'Wawancara, Bagian Kredit Bank Jambi'

Hans Kelsen. 2014. Teori Umum Tentang Hukum Dan Negara, General Theory Of Law and State, Terjemahan Raisul Muttaqien. Bandung. Nusa Media.

Riduan Syahrani. 1999. Rangkuman Intisari Ilmu Hukum. Bandung. Citra Aditya Bakti.

Sentosa Sembiring. 2000. Hukum Perbankan. Bandung. Mandar Maju.

\section{JURNAL HUKUM}

Bonny Oktafian, Ridwan dan Achmad Syarifuddin. 2019. 'Legalisasi Perjanjian Kredit Oleh Notaris Yang Berbeda Dengan Notaris Pembuat Covernote. Repertorium Jurnal Ilmiah Hukum Kenotariatan. Palembang. Universitas Sriwijaya

Dewi Rachmayani dan Agus Suwandono 2017. Notaris Dalam Perjanjian Kredit Dalam Perspektif Hukum Jaminan. Acta Diurnal Jurnal Hukum Kenotariatan Dan Ke-PPAT-An. Bandung. Universitas Padjajaran.

Dwi Wahyu Juliyanto dan Moch Najib Imanullah. 2018. Problematika Covernote Notaris Sebagai Pegangan Bank Untuk Media Realisasi Pembiayaan / Kredit Dalam Dunia Perbankan. Repertorium Jurnal Pemikiran Dan Penelitian Bidang Keprdataan Dan Kenotariatan. Solo. Universitas Sebelass Maret.

I Dewa Made Dwi Sanjaya. 2017. Tanggung Jawab Hukum Notaris Terhadap Penerbitan Covernote Dalam Pemberian Kredit. Riau Law Journal. Mataram. Universitas Mataram.

Mohammad Sigit Gunawan. 2018. Peran Dan Fungsi Covernote Notaris Pada 
Peralihan Kredit (Take Over) Pada Bank. Jurnal Ilmiah Indonesia. Cirebon. Universitass Swadaya Gunung Jati Cirebon.

Rahmanti, Novy Dyah Rahmanti. 2020. 'Ada Apa Dengan SKMHT?'. Recital Review. Jambi. Universitas Jambi.

Rahmiah Kadir, Farida Patittingi, Nurfaidah Said dan Muhammad Ilham Arisaputra. 2019. Pertanggungjawaban Notaris Pada Penerbitan Covernote. Repertorium Jurnal Ilmiah Hukum Kenotariatan. Makasar. Universitas Hasanudin

\section{PERATURAN PERUNDANG-UNDANGAN}

Undang-Undang Dasar Negara Kesatuan Republik Indonesia

Kitab Undang-Undang Hukum Perdata.

Undang-Undang Republik Indonesia Nomor 2 tahun 2014 tentang Perubahan Atas Undang-Undang Nomor 30 Tahun 2004 tentang Peraturan Jabatan Notaris .

Undang-Undang Republik Indonesia Nomor 10 Tahun 1998 Perubahan Atas Undang- Undang Nomor 7 Tahun 1992 Tentang Perbankan

Undang-Undang Republik Indonesia Nomor 4 Tahun 1996 tentang Hak Tanggungan 